\title{
A FIGURA DA VELHA FIANDEIRA NA TESSITURA DE CAMINHOS NA OBRA A PRINCESA E O GOBLIN DE GEORGE MACDONALD
}

\author{
THE FIGURE OF THE OLD SPINNER ON THE WAY TESSITURE AT WORK \\ THE PRINCESS AND THE GOBLIN BY GEORGE MACDONALD
}

Gabriela Soncini ${ }^{1}$

ORCID: http://orcid.org/0000-0003-4488-5210

\begin{abstract}
Resumo: Este artigo pretende fazer uma leitura da personagem "Velha Senhora", da obra A princesa e o goblin, publicada pela primeira vez em 1872, por George MacDonald. Essa misteriosa figura, através de uma presença insólita na narrativa, tece caminhos para a personagem Irene, princesa que se encontra no centro de um plano de sequestro, para ser levada às entranhas das montanhas pelas criaturas chamadas "goblins". Essa velha senhora será analisada aqui, através do imaginário da figura mítica da fiandeira. Para tal leitura ser realizada, será evocado neste trabalho o estudo "As fiandeiras" de Hughes Liborel, presente no livro Dicionário de mitos literários (2005), bem como outros pressupostos teóricos acerca dessas figuras. Como a personagem influencia de forma misteriosa os espaços e caminhos da história, além da viagem ascensional de Irene, traremos também estudos de Gaston Bachelard e Gilbert Durand, para ilustrar a questão espacial, celestial e temporal na personagem em questão.
\end{abstract}

Palavras-chave: Imaginário. Mitologia. Fiandeiras. Conto de fadas. Personagem.

\begin{abstract}
This article intends to read the character "Old Lady", of the work The princess and the goblin, first published in 1872, by George MacDonald. This mysterious figure, through an unusual presence in the narrative, weaves paths for the character Irene, princess who is at the center of a kidnapping plan, to be taken to the bowels of the mountains by creatures called "goblins". This old lady will be analyzed here, of the imaginary of the mythical figure of the spinner. For such reading to be performed, Hughes Liborel's study "The spinners" will be mentioned in this work, present in the book Dictionary of literary myths (2005). As the character mysteriously influences the spaces and paths of the story, in addition to Irene's ascending journey, we will also bring studies by Gaston Bachelard and Gilbert Durand, to illustrate the spatial, celestial and temporal issue in the character.
\end{abstract}

\footnotetext{
${ }^{1}$ Doutoranda em Estudos Literários na Universidade Federal de Uberlândia, desenvolvendo atualmente uma pesquisa sobre as imagens florais, transformações vegetais e metamorfoses em flores na mitologia, nos contos de fadas, e na obra do escritor dinamarquês de contos maravilhosos Hans Christian Andersen. Desenvolve estudos sobre as figuras míticas e maravilhosas, como fadas, elfos, sereias, gigantes, e demais criaturas do imaginário. É integrante do POEIMA - Grupo de Pesquisa Poéticas e Imaginário.
} 
G. Soncini A figura da velha fiandeira na tessitura de caminhos na obra A princesa e o

Goblin de George Macdonald

Keywords: Imaginary. Mythology. Spinners. Fairy tale. Character.

\section{Introdução}

A figura das fiandeiras é uma das presenças míticas mais misteriosas no imaginário de muitos povos. Segundo Hughes Liborel, no estudo "As fiandeiras", presente no livro Dicionário de mitos literários (2005), organizado por Pierre Brunel e vários outros pesquisadores, elas alimentam nos seres humanos desde os tempos mais remotos, a compreensão do desenrolar da existência, afinal, são elas que tecem o destino e o tempo dos seres.

A presença das fiandeiras pode ser encontrada em muitos mitos e histórias, sendo talvez as Moiras gregas um dos principais imaginários. Na mitologia, as Moiras são filhas de Têmis e Zeus: "Cloto é a fiandeira propriamente dita, Láquesis mede o fio, Ártropos é aquela a quem não se pode escapar” (LIBOREL, 2005, p. 375), juntas, elas fiam o destino de todos os homens. Na mitologia romana, as Moiras receberam o nome de Parcas, sendo seus nomes Nona, Décima e Morta. Também vemos a presença dessas mulheres misteriosas em diversos outros mitos de outras culturas, na mitologia escandinava, elas são chamadas de Nornas. De acordo com Jorge Luis Borges e Margarita Guerrero, em O Livro dos seres imaginários, os nomes delas são Passado, Presente e Futuro, e elas ficam junto a uma fonte ao pé da árvore Iggdrasill ${ }^{2}$, tecendo ali o destino dos homens:

O tempo (de que são feitas) as foi esquecendo, mas por volta de 1606 William Shakespeare escreveu a tragédia de Macbeth, em cuja primeira cena aparecem. São as três bruxas que predizem aos guerreiros o destino que os aguarda. Shakespere as chama de weird sisters, as irmãs fatais, as parcas. Wyrd, entre os anglo-saxões, era a divindade silenciosa que preside os mortais e imortais. (BORGES; GUERRERO, 2000, p. 180)

A essência do trabalho e a própria figura das fiandeiras repousam no mistério: "ninguém sabe onde nem quando transcorrem seus trabalhos. O fio do destino, como se vê,

\footnotetext{
2 Árvore cósmica da mitologia nórdica. Segundo Neil Gaiman (2017), em Mitologia nórdica, ela liga da sua raiz aos seus galhos, os nove mundos existentes em esferas diversas, como Asgard (o mundo dos deuses), e Midgard (o mundo dos homens). É interessante pensar na figura das Nornas ao pé dessa árvore próximas a uma fonte, como se estruturassem todos os mundos e destinos no início onde tudo cresce.
} 
G. Soncini A figura da velha fiandeira na tessitura de caminhos na obra A princesa e o

Goblin de George Macdonald

nasce do mistério" (LIBOREL, 2005, p. 375). Por mais que o próprio ser humano tente entender e prever seu próprio destino e futuro, acaba se deparando com o caráter nebuloso de seus caminhos: “Até o último século da civilização helenística, as Fiandeiras são a Lua Tripla, à semelhança de Ísis, e é em torno dessa figura que se forma o sincretismo religioso na Grécia Arcaica. De forma que o mito é a imagem do Único, que nada é capaz de embaraçar" (LIBOREL, 2005, p. 375). Assim, essa figura tripla tece o início, o meio e o fim da humanidade, de toda vida única.

Para além do mito, as fiandeiras, tecelãs, costureiras, bordadeiras, enfim, mulheres que trabalham com o fio, sempre tiveram presença nas sociedades arcaicas, e em diversas outras histórias e narrativas. No artigo "O tao da teia - sobre textos e têxteis", de Ana Maria Machado (2003), é desenvolvido de forma poética todo o caminho dessas mulheres que trabalharam e trabalham com fios e linhas. Machado (2003) elabora a aproximação dos termos de costura com o próprio fazer textual, como o termo novela/novelo, e assim tece de como privadas de terem presença em outras manifestações artísticas, o tecer, o costurar e o bordar, foram os meios das mulheres demonstrarem sua arte, de ocupar algum espaço na sociedade. Machado traz como exemplo a figura de Penélope, esposa de Ulisses da obra Odisséia de Homero, que tece uma mortalha durante o dia, e a desmancha durante a noite, para que assim pudesse adiar e não ter um casamento novamente. Na grande ausência de Ulisses, ela usa do tecer para conseguir ter escolhas.

Das três fiandeiras primordiais, muitos caminhos se delinearam em suas figuras presentes nos mitos, desdobrando-se em outras histórias e imagens, onde a personagem que fia liga-se com o fio, o fuso ou a roca: “Todas três terão atravessado as primeiras instâncias da oralidade de nossa humanidade, deixando em contos e lendas um fundo inalterável que é sua marca" (LIBOREL, 2005, p. 375). Podemos visitar inúmeros exemplos nos contos de fadas tradicionais, sendo a figura da fada fiandeira da Bela Adormecida ${ }^{3}$ a mais conhecida, e de acordo Hughes Liborel, as fadas são da linhagem das Parcas, suas imagens trazem a presença arcaica das fiandeiras. No conto, com a forma de uma fada malvada, ela encanta a princesa em seu nascimento, e depois como uma velhinha fiando, confirma o destino da jovem, que ao espetar o dedo na roca, adormece em um sono de cem anos. A fada/fiandeira

\footnotetext{
${ }^{3}$ Narrativa presente na coletânea Contos de fadas: de Perrault, Grimm, Andersen e outros (2010). A narrativa possui muitas versões, a mencionada neste trabalho, foi recontada pelos irmãos Grimm.
} 
G. Soncini A figura da velha fiandeira na tessitura de caminhos na obra A princesa e o

Goblin de George Macdonald

teceu o destino da jovem princesa, do qual não escapou, mas que teve um caminho diferente pela interferência das outras fadas.

Temos também o conto Rumpelstiltskin ${ }^{4}$, recolhido pelos irmãos Grimm, que conta a história de uma jovem que fia, e o pai admite ao rei que ela sabe fiar ouro. Ela acaba presa no castelo para fiar toda palha em ouro, e desesperada por não poder fazer isso, começa a chorar, e desse choro aparece um homenzinho estranho que promete fiar a palha em ouro para ela, se a mesma lhe prometesse seu primogênito quando nascesse. Ana Maria Machado (2003) resgata a primeira versão desse conto, que ao contrário, a jovem se desespera por não conseguir fiar normalmente, e sim apenas ouro, salientando assim a mudança de versões e principalmente da visão destinada às fiandeiras, que em um período artesanal de existência tinham muito valor, fiavam "ouro", e após o advento das máquinas, não conseguiram mais ter esse prestígio de outrora.

Há outro conto chamado "As três fiandeiras" 5 , no qual uma menina não sabe fiar e é castigada por isso pela sua mãe. A rainha que passava em caminho próximo no momento, pergunta o porquê da mãe estar sendo ríspida com a filha, e ela mente dizendo que era porque não conseguia tirar a filha da fiação. A moça é então levada para o castelo para fiar imensas quantidades, não consegue, e é nesse caso, diferente de Rumpelstiltskin, ajudada pelas três fiandeiras, uma apresentando o pé disforme, a outra o lábio, e a terceira o dedo. Elas exigem da moça a participação na festa do seu casamento com o príncipe, que é posteriormente concedida. O príncipe, porém, estranha as mulheres e as acha horrorosas, perguntando a respeito de suas deformidades. Quando elas respondem que é devido à fiação incessante, o príncipe proíbe a jovem com quem se casou de fiar, assim a moça se vê livre de tal atividade que nunca executou. Aqui vemos até uma espécie de crítica ao trabalho de fiar, bem como a ideia da mulher ser destinada apenas para atividades de tecer.

A figura das fiandeiras e tecelãs caminham sobre uma ambivalência, elas são temidas por fiarem o destino dos homens, porém, em muitas personagens, o fiar também salva suas próprias vidas. No conto irlandês "As mulheres chifrudas" ${ }^{6}$ de Lady Wilde, percebemos essa presença maléfica nas fiandeiras. Em uma noite quando uma mulher fia, ela escuta batidas nas portas, e entram uma por uma, bruxas fiandeiras que começam a fiar lã, as

\footnotetext{
${ }^{4}$ Versão presente em Contos dos irmãos Grimm (2005), organizado pela Dra. Clarissa Pinkola Éstes.

${ }^{5}$ Conto coletado pelos irmãos Grimm, recontado por Viriato Padilha em Histórias do Arco da Velha (1947).

${ }^{6}$ Conto presente no livro Os melhores contos de fadas celtas da editora Wish (2020).
} 
G. Soncini A figura da velha fiandeira na tessitura de caminhos na obra A princesa e o

Goblin de George Macdonald

mulheres são assustadoras com chifres nas testas, a começar por um, até a última que tem doze chifres. Nesse conto percebemos também a relação das fiandeiras com as bruxas, assim como a crença também delas serem mais que três, desdobrando-se em outras. O que fica nesse conto, é o terror da personagem em relação às figuras misteriosas que aparecem sem motivo aparente.

Outras personagens remontam às velhas fiandeiras primordiais, como Ariadne ${ }^{7}$ que entrega o fio a Teseu, para que este possa encontrar os caminhos dentro do labirinto do Minotauro, sendo este exemplo importante para nossa análise, pois se trata de um fio condutor da travessia pelo espaço, o que irá acontecer em A princesa e o goblin (2003). Temos também a história de Aracne ${ }^{8}$, jovem que admite fazer tapeçarias mais lindas do que as da própria deusa Atena. Através da ira da deusa, a jovem é transformada em uma aranha, condenada a tecer por toda sua vida. E falando em aranhas, é com essa figura do reino animal, que Ana Maria Machado (2003) abre seu pensamento em "O tao da teia - sobre textos e têxteis". A aranha que constrói sua teia com os fios que saem do seu próprio corpo, é uma figura exemplar para as fiandeiras, já que para muitos estudiosos, como veremos mais adiante, evidenciam que a forma circular que a mulher fica na roca, é uma extensão da sua própria figura corporal.

Diante desta breve apresentação, este artigo pretende realizar uma leitura da personagem "Velha Senhora", presente na narrativa de George MacDonald. Apesar de pouco conhecido como escritor e pouco estudado em meios acadêmicos, MacDonald exerceu grande influência com sua escrita e histórias de caráter maravilhoso nas obras de escritores como J.R.R. Tolkien e C.S. Lewis ${ }^{9}$. A obra de MacDonald também foi pouco traduzida no Brasil, tendo poucos títulos como Phantastes: A terra das fadas (2015), A chave dourada (2012) e "A princesa leve", publicada recentemente na coletânea Os melhores contos de fadas celtas (2020).

De educação cristã, assim como os escritores que se inspiraram em suas obras, MacDonald traz em suas histórias figuras mágicas e míticas, sempre buscando tecer um fundo de ensinamento cristão e moral, porém, sua obra não pode ser reduzida apenas nesta

\footnotetext{
${ }^{7}$ História evocada em Metamorfoses (2003) de Ovídio.

${ }^{8}$ Presente em Metamorfoses (2003) de Ovídio.

${ }^{9}$ Tolkien escreveu a conhecida obra $O$ senhor dos anéis, publicada pela primeira vez em 1954, que utiliza a mitologia nórdica e inspirações em outros contos clássicos, e Lewis escreveu As crônicas de Nárnia, também publicada em 1954.
} 
G. Soncini A figura da velha fiandeira na tessitura de caminhos na obra A princesa e o

Goblin de George Macdonald

leitura, já que ela traz diversas imagens. A Velha Senhora, personagem que aqui será analisada, parece ser uma figura protetora e santa como a virgem Maria, e encontramos nela resquícios das fiandeiras primordiais, e através deste caminho, que seguiremos esse fio condutor visitando nela outras fiandeiras. É importante salientar que essa leitura procura realizar um estudo de uma personagem e sua influência nos trajetos espaciais da narrativa, certamente outras leituras podem ser feitas na exploração da própria personagem, da história em geral e dos outros personagens, que serão brevemente apontados aqui neste trabalho.

\section{"Uma senhora muito velha fiando..."}

Na obra A princesa e o goblin, é narrada a história da princesa Irene, que no começo da narrativa tem cerca de oito anos de idade. A princesa mora em uma casa de campo do próprio rei seu pai, e é cuidada pela aia Lootie e outros empregados. É descrito no início do livro, que sua mãe era frágil em saúde quando a menina nasceu, mas não é explicado se a rainha de fato veio a falecer com o nascimento da filha, e também não é explorado o porquê de a menina ter sido enviada para a casa de campo, ao invés da mesma permanecer no castelo. Muitos estudiosos atribuem o afastamento ao costume histórico dos grandes monarcas, de deixarem o cuidado dos filhos para aias e outros empregados, longe até mesmo do próprio castelo, até terem certa idade para retornarem.

Nesta grande casa, a menina brinca e tem suas pequenas aventuras em um imenso jardim, e desconhece, pela sua inocência e falta de comunicação com os outros, a existência dos goblins, descritos pelo autor como figuras descendentes dos humanos, que em determinada época desceram para dentro das montanhas, ficando "diferentes":

Ora, nessas cavernas subterrâneas vivia uma estranha raça de seres, chamados por alguns de gnomos, por outros de duendes, e por outros de goblins. Uma lenda corrente no país dizia que houve um tempo em que eles viveram na superfície e eram muito parecidos com os humanos. (MACDONALD, 2003, p. 2)

Assim, a história se tece por uma espécie de dualismo entre o "mundo de cima" dos homens, e o "mundo de baixo" dos goblins, que é perpassado pela figura dos mineiros, que são humanos e vivem no mundo de cima, porém trabalham no mundo de baixo dentro das 
G. Soncini A figura da velha fiandeira na tessitura de caminhos na obra A princesa e o

Goblin de George Macdonald

montanhas. Essas criaturas parecem ter um desejo de vingança, então tramam duas espécies de ataques, um sendo o sequestro da princesa para que ela se case com o príncipe dos goblins, e outro a inundação do mundo humano. Ficamos sabendo desses planos através do personagem Curdie, um menino mineiro de cerca de doze anos de idade, que sempre vive a explorar os caminhos das montanhas. Curdie será um personagem essencial para a história, e é importante salientar que a presença dos mineiros nas montanhas é bastante incômoda para os goblins, já que eles assim como as criaturas adentram as profundezas da terra.

A princesa Irene só tem consciência da existência dos goblins em um dia de passeio descuidado pelas montanhas com sua aia Lootie. Elas são atacadas pelos goblins, que já tinham o desejo de sequestrar a princesa, e são salvas por Curdie, que tem o conhecimento pela sua experiência nas montanhas, que as criaturas odeiam versos, e que declamá-los e cantá-los os irritam e os expulsam. Este desgosto com os versos humanos tem um caráter de uma perda na história, ou seja, de certa humanidade perdida pelos goblins, da qual eles tinham no passado.

Um dia quando a princesa está entediada em casa com o dia de chuva que fazia, ela resolve explorar os caminhos não conhecidos da grande casa, e se depara com estranhas escadas que a levam para cima, onde se encontram muitos corredores cheios de portas, que, ao serem abertas, continuam conduzindo para o alto. Esta simbologia da escada conduzindo às alturas, já evoca a natureza da personagem que será encontrada, como se ela pertencesse à outra esfera de existência. Segundo Gilbert Durand em As estruturas antropológicas do imaginário: introdução à arquetipologia geral (2012), a escada é um dos símbolos ascensionais, e que as características das escadas míticas serão sempre celestes, e veremos na figura da velha senhora, que ela é cercada por símbolos celestes.

Apesar do medo e do pânico dessa subida, Irene acaba encontrando o caminho ou é levada para ele, iniciando assim, como explora Durand (2012), uma viagem imaginária pelo lugar supraceleste:

Ao chegar ao topo, ela se viu em uma pequena área retangular com três portas, duas opostas entre si, e uma oposta ao topo da escada. Parou por um momento, sem ideia na sua cabeça do que fazer em seguida. Mas, enquanto estava ali, começou a ouvir um zumbido curioso. Seria a chuva? Não. Era muito mais suave e até mais monótono do que o som da chuva, que agora ela mal ouvia. O som doce e baixou prosseguiu, às vezes parava por algum tempo e depois começava novamente. Era mais parecido com o 
G. Soncini A figura da velha fiandeira na tessitura de caminhos na obra A princesa e o

Goblin de George Macdonald

zumbido de uma abelha muito feliz que tivesse encontrado uma rica fonte de mel em alguma flor globular do que qualquer outra coisa que me ocorra neste momento. (MACDONALD, 2003, p. 7).

Na terceira porta, e aqui já vemos a essência tripla das fiandeiras, Irene encontra uma senhora muito velha fiando, na verdade, a sensação que paira é a de ser uma senhora velha e muito antiga, mas para além da sua aparência, fica um mistério de sua verdadeira idade:

Talvez você queira saber como a princesa podia dizer que a senhora velha era uma senhora velha, quando eu lhe disser que ela era não somente muito bonita, mas tinha a pela macia e branca. Direi mais. Seu cabelo estava penteado para trás, era longo e caía espalhado sobre as costas. Isso não se parece bem com uma velha senhora, não é? Ah! mas era branco quase como a neve. E apesar do rosto tão macio, seus olhos pareciam tão sábios que você não poderia ter evitado pensar que ela deveria ser velha. A princesa, embora não pudesse dizer-lhe porque, pensou que ela era verdadeiramente muito velha - bem nos cinquenta, disse para si mesma. Porém, ela era um tanto mais velha, como você verá. (MACDONALD, 2003, p. 8).

A velha senhora fica feliz de ver a princesa, e, pelo seu primeiro diálogo, percebemos o início da viagem ascensional da princesa, que como já salientado, fica mais evidente também com o plano dos goblins de levá-la para as entranhas abaixo da terra. Assim, a figura ascensional da velha senhora, virá de encontro de uma forma opositiva à descida planejada. Essa figura será essencial neste momento importante para a princesa, que terá que posteriormente na narrativa adentrar a montanha para salvar:

\footnotetext{
"Ora, o que você esteve fazendo com seus olhos, filha? Perguntou a senhora.

"Chorando", respondeu a princesa.

"Por que, meu bem?"

"Porque não podia encontrar meu caminho para baixo".

"Mas você conseguiu encontrar seu caminho para cima". (MACDONALD, 2003, p. 8).
}

Esse encontro, também evidencia o caráter mítico das fiandeiras ligado às coisas celestes. Segundo Liborel (2005), elas residem nas águas celestes, nas águas primordiais: “É lá que essas divindades das águas celestes, fazem cair chuva e orvalho. As substâncias da natureza são apreendidas como um tecido" (p. 370). De acordo com Ana Maria Machado: 
G. Soncini A figura da velha fiandeira na tessitura de caminhos na obra A princesa e o

Goblin de George Macdonald

"Para os gregos, o fuso e a roca eram uma imagem do cosmos que continha o fuso de Platão, rodeado por um círculo de fogo e água. Água do Letos, o rio do esquecimento. Situados fora do espaço, no mundo ideal, excluídos da realidade" (2003, p. 180). Portanto, a figura das fiandeiras está em um entre-espaço, em um entre-lugar, fora do mundo dito real, mas que exerce influência neste. E é com essa ligação com as águas, a natureza e o céu, que se dará a fiação dessa velha senhora, que analisaremos agora.

\section{A fiandeira na figura da "tetravó"}

Segundo Gilbert Durand (2012), devido à imaginação da ascensão, nós desejamos vencer as quedas. Além da jornada ascensional de Irene, vemos também o simbolismo da queda nos goblins, que já habitaram a terra um dia, mas caíram em suas montanhas e cavernas, e assim desejam também afundar aqueles que continuam em cima. A velha senhora representa, dessa forma, um estágio mais alto de ascensão que o próprio mundo humano. Ela se apresenta para Irene como sua antiga tetravó, de uma forma até confusa, ela diz que é até mais antiga que uma simples tetravó, portanto, podemos ler a personagem como uma figura ancestral, familiar e através de uma presença mítica, que se projeta para além deste mundo: uma figura do imaginário humano. Sua característica de elevação também está presente em sua própria aparência:

Quando ela saiu levando a bacia e a tolha, a princesinha admirou-se ao ver como a senhora era ereta e alta, pois, apesar de tão velha, não era nem um pouquinho curvada. Estava vestida de veludo preto enfeitado com renda de aspecto pesado, branca e espessa, e sobre o veludo preto seu cabelo brilhava como prata. Não havia mais peças de mobília no quarto, além daquelas que podia haver no quarto da mais pobre velha que ganhasse o pão com sua fiação. Nenhum tapete no assoalho - nenhuma mesa ali nada, a não ser a roca e a cadeira ao lado. Ao voltar, a senhora sentou-se novamente, e, sem dizer uma palavra, recomeçou mais uma vez a fiar, enquanto Irene, que nunca vira uma roca, permanecia ao seu lado e olhava. (MACDONALD, 2003, p. 9).

A velha senhora também diz ter o mesmo nome de Irene, confirmando ainda mais seu caráter de ancestralidade com a menina, e também de mistério em relação a seu próprio nome original. Giorgio Agamben, em "Magia e felicidade", presente no livro Profanações (2007), elabora que a magia não é conhecimento de nomes, mas desvio em relação a eles: 
G. Soncini A figura da velha fiandeira na tessitura de caminhos na obra A princesa e o Goblin de George Macdonald

"A magia é, essencialmente, uma ciência de nomes secretos. Cada coisa, cada ser, tem, além de seu nome manifesto, um nome escondido, ao qual não pode deixar de responder” (p. 25), Podemos dizer que Irene é o nome que a personagem decide usar ali, não manifestando completamente seu verdadeiro nome para a princesa: "Livre de nome, bem aventurada, a criatura bate à porta da aldeia dos magos, onde só se fala por gestos" (AGAMBEN, 2007, p. 25), esse falar por gestos, trata-se dos mistérios que as criaturas mágicas evocam, afinal, a velha senhora fala com Irene por gestos, códigos, por mistérios, sem responder totalmente o que é. A personagem ainda salienta no diálogo, que se encontra na casa de campo do rei desde que a princesa fora morar ali, para cuidar dela, tendo uma essência de guardiã da menina, mas veremos que ela também já se manifestou para outras pessoas, sendo uma figura ambivalente, uma fada-madrinha um tanto estranha.

Ela habita o mais alto da casa, embora dentro de uma esfera espacial estranha e insólita. Ela possui aves neste "sótão" misterioso, o que nos permite evocar Gaston Bachelard (1990), que ilustra que: “A casa é um arquétipo sintético, um arquétipo que evoluiu. Em seu porão está a caverna, em seu sótão está o ninho, ela tem raiz e folhagem" (p. 81). Os pássaros da personagem habitam esse sótão/ninho dessa casa, como uma árvore mística, onde a velha senhora se encontra na copa fiando, um detalhe diferente das Nornas escandinavas, que fiavam ao pé da árvore Iggdrasill, segundo Borges e Guerrero (2000).

Este aspecto da casa que Bachelard salienta, fica ainda mais evidente quando os goblins tentam invadi-la posteriormente através do porão para sequestrarem a princesa: "Mas o porão é tão nitidamente a região dos símbolos do inconsciente que de imediato fica evidente que a vida consciente cresce à medida que a casa vai saindo da terra" (1990, p. 82). Para o estudioso, a casa de campo representa ainda mais essa riqueza onírica, da casa que brota da terra, na qual Irene na história reside.

A figura da velha senhora que fia neste patamar mais alto da casa, e sua presença etérea, também evidencia que: "A casa encontra-se na fronteira de dois mundos" (BACHELARD, 1990, p. 89). A personagem não pode descer as escadas para ir até o meio humano, pois se trata de um ser de outra materialidade e imaginário, portanto, sua presença se apresenta de outras formas no mundo humano, e até mesmo nessa outra esfera que a casa abre caminho, onde só Irene consegue vê-la.

A princesa tenta procurá-la novamente depois do primeiro encontro, porém ela só aparece para a menina quando realmente deseja. Certa vez a princesa machuca seu dedo em 
G. Soncini A figura da velha fiandeira na tessitura de caminhos na obra A princesa e o

Goblin de George Macdonald

um broche, e ao despertar com muita dor, sobe as escadas novamente em busca da velha senhora, em uma clara alusão ao conto da Bela Adormecida, que espeta seu dedo em um fuso. Aqui o broche parece ser um objeto representativo da outra esfera que a fiandeira fia em sua roca. Ao encontrá-la dessa vez, a velha continua fiando ao luar, e pergunta a Irene se ela sabe o que ela está fiando, o que a menina responde não saber:

"Você ainda não me disse o que estou fiando", ela falou.

"Porque não sei. É um tecido muito bonito". Era de fato um tecido muito bonito. Havia um bom fardo dela na roca junto à roda de fiar, e ao luar brilhava como - o que posso dizer que parecia? Não era suficientemente branco para ser prateado - sim parecia prata, mas o brilho estava mais para cinzento do que para branco, e brilhava só um pouquinho. E o fio que a velha senhora puxava dali era tão fino que Irene mal podia enxergá-lo. "Estou tecendo isto para você, meu bem." "Para mim! Por favor, o que farei com isso?" "Eu lhe direi mais tarde. Mas primeiro vou contar-lhe o que é. São teias de aranha - de um tipo especial. Meus pombos as trazem para mim além do grande mar. Existe somente uma floresta onde vivem as aranhas que fazem esse tipo especial - o mais fino e forte de todos. Já quase acabei minha tarefa. O que está na roca agora será bastante. Entretanto, ainda tenho uma semana de trabalho ali", ela acrescentou olhando o fardo. (MACDONALD, 2003, p. 52).

A fiandeira só trabalha nas noites de lua cheia, segundo Liborel (2005), a noite é o momento das fiandeiras míticas fiarem, sendo as Moiras filhas da noite. E neste momento, também vemos a associação com o mito de Aracne, onde o fio que a velha senhora tece é de aranhas especiais, vindo de terras míticas. Esse fiar incessante, também pode ser entendido como a construção da própria fiandeira no espaço sagrado, afinal, vai ser através do resultado dessa fiação, que ela protegerá Irene e conduzirá o caminho da narrativa: "Fiando incessantemente, a fiandeira construiria para si a possibilidade de introduzir-se num outro mundo. Seria aquele do sagrado, que se mantém sempre para além do mundo profano" (LIBOREL, 2005, p. 374).

Ao ver o machucado de Irene feito pelo broche, a velha senhora conduz a menina até a porta misteriosa de seu quarto, um cômodo feito de vários elementos celestes, com uma abóboda no teto repleto de estrelas. Os dois detalhes mais expressivos são a luminária lunar, que é o sinal que a velha fiandeira deixa aparecer aos demais ${ }^{10}$; evocando ainda mais sua

\footnotetext{
${ }^{10}$ Em dado momento da narrativa, a mãe de Curdie, conta que um dia viu uma misteriosa luminária em forma de lua voando pelo céu, uma espécie de orbe, que a conduziu quando ela estava perdida. Essa história é narrada para o menino no momento posterior da narrativa, em que ele duvida da princesa Irene e de sua história com a
} 
G. Soncini A figura da velha fiandeira na tessitura de caminhos na obra A princesa e o

Goblin de George Macdonald

ligação com a noite e com o astro celeste; e um estranho buquê de rosas vermelhas. No terceiro encontro com a fiandeira, ficamos entendendo que as rosas vermelhas eram uma espécie de lareira:

Irene olhou então, e viu que aquilo que imaginara ser um enorme buquê de rosas vermelhas era de fato fogo aceso; tinha a forma das mais lindas rosas vermelhas e faiscava esplendidamente entre a cabeça e as asas de dois querubins de prata brilhante. E quando ela se aproximou, verificou que o perfume das rosas que enchia o quarto vinha das rosas do fogo da lareira. Sua avó estava vestida no mais lindo tom de veludo azul-pálido, e o cabelo dela não era mais branco, mas de uma rica cor dourada. Caía como uma catarata, ora em massas foscas, ora em torrentes macias e brilhantes. E quanto mais ela olhava, o cabelo parecia despejar-se de sua cabeça e desaparecer numa névoa dourada antes de alcançar o chão. Fluía das bordas de um diadema de prata brilhante cravejado alternadamente de pérolas e opalas. Não havia ornamento algum no seu vestido, nem anel em seus dedos, ou colar ou corrente no pescoço. Mas seus chinelos brilhavam como a luz da Via Láctea, pois estavam cobertos com minúsculas pérolas e opalas. Seu rosto era de uma jovem de 23 anos. (MACDONALD, 2003, p. 66).

Percebemos nessa descrição, mais elementos celestes em suas vestimentas e um cabelo etéreo que parece ser feito de outra matéria, que se desmancha através da visão. Bachelard evoca em A chama de uma vela (1989), que as imagens de flores em chama, ou seja, as chamas da flor, são animadas pela chama da palavra. As flores que queimam em uma lareira são uma espécie de magia da velha fiandeira, e as imagens em forma de rosas também evocam o simbolismo dessa flor: "Entre todas as flores, a rosa é realmente uma lareira de imagens para a imaginação das chamas vegetais. Ela é o próprio ser da imaginação imediatamente convencida" (BACHELARD, 1989, p. 84). A flor também pode ser entendida como um símbolo de vida: "A chama da vida do ser que floresce é uma tensão em direção ao mundo da pura luz" (p. 88). As flores que florescem em chamas, indicam um caminho para a pura luz que de sua figura emana.

A cada encontro, percebemos que a estranha mulher rejuvenesce, salientando sua misteriosa idade e seu estado maravilhoso, o que Liborel (2005) também destacou, como o fato dos seres humanos serem deixados na ignorância a respeito da verdadeira idade e forma

velha senhora. A narrativa contada pela mãe é essencial para que o menino tivesse outro olhar em relação aos fatos, e a mãe de Curdie também será importante no clímax da história, pois é ela que vai acalentar Irene em sua casa quando os goblins invadirem a casa de campo do rei. 
G. Soncini A figura da velha fiandeira na tessitura de caminhos na obra A princesa e o

Goblin de George Macdonald

das fiandeiras: elas são velhas, mas jovens, elas parecem carregar todas as idades dentro de si, delineando o trajeto de vida do ser humano, desde a tenra idade até a morte, tecendo esses fios. A velha senhora alimenta e é alimentada com outra luz, proveniente de outro espaço e tempo, estranha e incompreensível aos seres humanos, essa outra luz que permite adotar a idade e a aparência que deseja.

\section{O fio condutor dos caminhos}

Segundo Eliane Campello, no artigo "A tessitura do caminho: do mito à expressão pela arte": "Todos os mitos que envolvem a tecelã ou a fiandeira demonstram que o poder recai justamente no fato de a mulher lidar com o fio, e, por meio de sua ação, determinar o destino da humanidade" (2008, p. 43). E é assim que também se desenvolve em A princesa e o goblin, onde a presença da fiandeira é fortemente colocada no destino da história em questão e dos personagens. No terceiro encontro, e aqui vemos mais uma vez a simbologia tripla, a velha senhora entrega a Irene uma pequena bola, resultado de sua fiação. A menina estranha por se tratar de um objeto tão pequeno, para tanto trabalho que ela teve de fiar. Essa pequena bola é colocada dentro de um anel, e neste momento vemos uma grande força que é miniaturizada. Bachelard, em A poética do espaço (1988), salienta que a imagem da miniatura é uma das moradas da grandeza: “A miniatura é repousante, sem jamais fazer adormecer. A imaginação permanece vigilante e feliz” (p. 168). A pequena bola guarda uma grande fiação, que, por conseguinte, é guardada em um pequeno anel, objeto mágico. Irene se sente feliz com o anel mágico, um presente que a acalenta apesar do mistério que o envolve.

A velha senhora coloca o anel no dedo da menina, e tira de dentro dele um fio invisível, e o amarra na bola tecida, e a guarda em seu próprio armário, estabelecendo uma ligação entre o anel no dedo da menina e seu armário, com a sua espacialidade, e aconselha a princesa a usar o anel em momento de necessidade. Ficamos sabendo que a pequena bola guarda o fio fino demais, feito das teias das aranhas do além das outras águas, um fio que é possível mais sentir do que ver:

"Oh! estou sentindo!", exclamou a princesa. Mas não posso vê-lo, acrescentou olhando bem de perto para sua mão estendida. 
G. Soncini A figura da velha fiandeira na tessitura de caminhos na obra A princesa e o

Goblin de George Macdonald

\begin{abstract}
"Não. O fio é fino demais para que você possa enxergá-lo. Você só pode senti-lo. Agora você pode imaginar a quantidade de fiação que foi necessária, embora pareça mesmo uma bola pequena.

"Mas o que posso fazer com ela se está em seu armário?"

"É isso que vou lhe explicar. Não adiantaria nada para você, não seria sua de modo algum se não ficasse em meu armário. Agora preste atenção. Se estiver em algum perigo, por exemplo, como você esteve nesta noite, você deve tirar o anel e colocá-lo em baixo do travesseiro de sua cama. Depois você deve pôr o dedo indicador, o mesmo onde esteve o anel, sobre o fio e segui-lo, seja qual for a direção para onde ele a conduzir. (MACDONALD, 2003, p. 70).
\end{abstract}

Portanto, o fio que a velha senhora entregou a menina, trata-se de um modo de condução a um caminho em momento de necessidade. Lembremos agora do personagem Curdie, o menino mineiro. Certo dia, ele adentra muito fundo nas entranhas da montanha, para tentar descobrir o segredo dos goblins, ele desconfiava que as criaturas estavam tramando algo, e é capturado por eles. Em uma noite que Irene acorda com a sensação de medo, ela coloca o anel abaixo do travesseiro, e sente uma mão tocar a sua, e logo após sente o fio mágico e resolve o seguir. $\mathrm{O}$ fio acaba a levando para dentro da montanha, mesmo que não saiba que ele estaria a conduzindo para o resgate de Curdie. Irene com muito medo resolve seguir, confiando nos caminhos do fio, e faz uma descida pela montanha, aqui se contrapondo à queda evocada no regime diurno da imagem por Durand (2012). No regime noturno, essa queda se eufemiza em descida, e isso fica evidente na princesa, que conduzida pelo fio mágico da figura celeste, noturna e maternal da fiandeira, "desce" para as profundezas da terra.

É aqui que o fio se assemelha ao fio de Ariadne para a condução dos caminhos: "O fio mágico de Ariadne merece nossa atenção. É ele que dá a Teseu o poder e os meios de continuar vivo. Dom quase da imortalidade. O fio é de desejo, de proteção e de conservação" (LIBOREL, 2005, p. 379). Dentro da montanha, os caminhos são labirínticos, mas o fio da velha fiandeira não falha, e conduz Irene até Curdie. O mesmo fio que conduziu a descida, também agora conduz a subida para fora da montanha, porém, Curdie não o sente neste momento da narrativa chegando a duvidar de Irene: "A profundeza dentro das coisas procede da mesma dialética do aparente e do oculto. Mas essa dialética logo é trabalhada por uma vontade de segredo, por devaneios que reúnem segredos poderosos" (BACHELARD, 1990, p. 196). O fio ainda é oculto ao menino. 
G. Soncini A figura da velha fiandeira na tessitura de caminhos na obra A princesa e o

Goblin de George Macdonald

Este fio também é representativo da viagem, que conduz os personagens de volta, como a imagem do fio da ninfa Calipso em Odisséia (2014), que transforma seus fios nas velas da embarcação do herói: “O fio cósmico, maléfico, protetor ou iniciático, é o fio da história que liga os mundos e os estados: mundo visível e invisível” (LIBOREL, 2005, p. 382). Os desejos do fio da velha senhora fiandeira se revelam nesta narrativa como protetores, como um meio para que os personagens sejam salvos dos goblins, que aqui representam as profundezas e a queda. O fio é mágico, se eufemiza em descida para salvar e subida ascensional.

Este fio irá se revelar mais uma vez protetor. No momento do temido ataque dos goblins na casa de campo do rei, na tentativa de sequestro da princesa, Irene será mais uma vez salva pelo fio, que a levará para a casa da mãe de Curdie. Este fio será revelado para o menino, que o sentirá em momento de encontrar Irene. Ele será visitado em sonho pela velha senhora, que irá se revelar para o outro personagem com outros meios, diferentes de sua presença com a princesa. Curdie encontrará a menina que todos julgavam realmente sequestrada pelos goblins, na grande confusão que foi a invasão deles na casa de campo. Então, o fio que levou para dentro da montanha, levará para o alto dela, para o lar de Curdie, onde Irene se encontra protegida com a mãe do menino que a acalenta e conta histórias.

\section{Considerações finais}

Por fim, mesmo sendo salvos, a inundação da casa acontece, e os personagens quando estavam fugindo de toda a água, vêem a luminária da velha senhora pairando no céu, que de certa forma continua em sua outra esfera, fiando nas noites de luar, fiando sempre novos caminhos para outros personagens para os quais ela resolva aparecer novamente, na busca por jornada de ascensão.

Muitos outros elementos poderiam ser aqui analisados na figura dessa velha fiandeira, seus elementos celestes e sua lareira florida apresentam muitas imagens que poderiam ser mais aprofundadas, sua banheira curativa das águas primordiais, na qual Irene mergulha em dado momento da narrativa, e até mesmo seu armário que guarda o fio condutor, que foram aqui apenas colocados para delinear essa figura insólita: "Os objetos guardados no 'armário de coisas' (chosier), nesse estreito mundo de coisas que gostamos, são talismãs da fantasia. Evocamo-las e pela graça de seus nomes, já vamos sonhando 
G. Soncini A figura da velha fiandeira na tessitura de caminhos na obra A princesa e o

Goblin de George Macdonald

histórias bem velhas." (BACHELARD, 1989, p.92). O fio guardado no armário do outro reino, ligado ao nosso mundo, produz ecos e lembra-se de histórias e figuras velhas, como da senhora fiandeira, que é uma nessa narrativa, mas também três, em diversas idades.

A velha fiandeira é essa figura que pode começar e interromper, e em A princesa e $o$ goblin, vemos nela o "continuar", é a Cloto que irá fiar, representa o meio do caminho, o trajeto que vai continuar. A casa se foi, mas os personagens não, e talvez agora Irene vá ao seu novo lar no castelo, abandonando a tenra infância. Ela teve seu momento iniciático, tão assinalado por mitos e contos de fadas.

Aqui temos a figura arcaica da fiandeira em uma nova leitura, tal como Bachelard (1997) evoca: “A imaginação é uma sonoplasta, deve amplificar ou abafar” (p. 201). A história se tece entre as alturas e as profundezas dos seres, tal como evoca Novalis (2001): "A fantasia põe o mundo futuro seja na altura, ou na profundeza, ou na metampsicose, em relação a nós" (p. 43). Segundo ainda Novalis, o mundo feérico é uma espécie de mundo pátrio, que está em todo lugar, mas ao mesmo tempo em lugar nenhum, assim como a velha senhora, que está na casa, mas não está. Sua luminária está no mesmo céu que o nosso, mas ao mesmo tempo não está: "as potências superiores em nós, que um dia, como gênios, cumprirão nossa vontade, são agora musas, que nesta fadigosa trilha nos recreiam doces recordações" (2001, p. 163). A aparição da fiandeira vinda desse outro espaço misterioso conduz ao espaço dito real, pois dentro desses espaços paralelos, os mundos se encontram e conduzem a outros.

Esta breve história em forma de conto de fadas, ainda tece motivos arcaicos dentro de nós leitores. O gesto de fiar da fiandeira trabalha na própria noção espacial:

Gesto e utensílio trabalham no sentido de uma corporificação do espaço. Engendram-se mutuamente. Como o mito, eles se fazem presentes desde a origem: objetos escolhidos, mostrados com precisão e em definitivo. Objetos fixos que se deslocam em círculos repetidos, sempre os mesmos ao longo do tempo. (LIBOREL, 2005, p. 371).

As fiandeiras representam o desenrolar da existência temporal e espacial. Em outros espaços celestes, no mundo sagrado, elas fiam os tecidos que irão marcar os caminhos, são arquitetas dos momentos mais antigos: "No conto, particularmente, o fio é vínculo e caminho, e aquele que o fabrica marca nele etapas e entroncamentos" (LIBOREL, 2005, p. 
G. Soncini A figura da velha fiandeira na tessitura de caminhos na obra A princesa e o Goblin de George Macdonald

374). E evocamos aqui o quadro de Diego Velázquez “As fiandeiras”, também chamado de "A fábula de Aracne", para demonstrar que além da literatura, o mito das fiandeiras também reverberou em várias outras linguagens artísticas. Na pintura, vemos a roda girando sem parar, dando uma intensa sensação de eterno movimento:

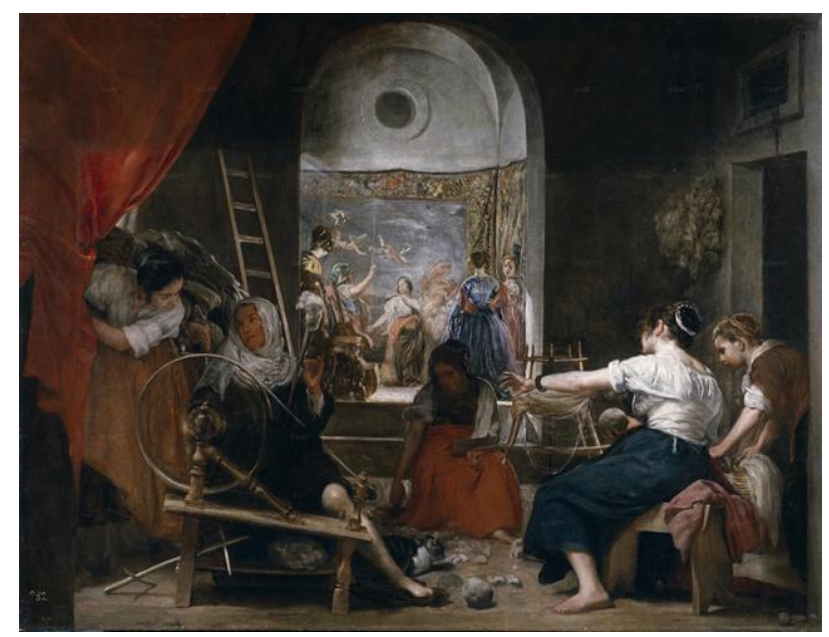

As Fiandeiras (1656-58), óleo sobre tela, Diego Velázquez, Museu do Prado, Madri.

De acordo com Liborel (2005), o fuso, utensílio das fiandeiras, simboliza o Eterno Retorno: "O ciclo - movimento uniforme e rotativo - é então o gesto de ligação entre as Moiras; ele engendra todos os outros gestos exigidos pela fiação para recuperar cada um deles em sua precisão e em sua unicidade" (p. 375). Tanto nos contos de fadas como na pintura de Velázquez, assim como na história aqui evocada, podemos visualizar a representação de toda essa ideia de movimento cíclico, de ligação com as etapas da vida.

A fiandeira pode cessar uma vida, mas também a entrega em principio e continuidade para todos aqueles que, apesar de se perderem ao subir a escada ascensional, continuam. Ao chegarem às portas triplas da existência, talvez ali encontrem a velha senhora fiandeira, que fia com teias de aranha do além mar, um fio imperceptível, que ajudará a transpor as profundezas e as quedas, as transformando em descidas conduzidas pelo fio mágico, para subir então nas montanhas sagradas.

\section{Referências}

AGAMBEN, Giorgio. Profanações. Trad. Selvino J. Assmann. São Paulo: Boitempo, 2007. 
G. Soncini A figura da velha fiandeira na tessitura de caminhos na obra A princesa e o Goblin de George Macdonald

BACHELARD, Gaston. A água e os sonhos: ensaio sobre a imaginação da matéria. Trad. Antônio de Pádua Danesi. São Paulo: Martins Fontes, 1997.

BACHELARD, Gaston. A chama de uma vela. Trad. Glória de Carvalho Lins. Rio de Janeiro: Bertrand, 1989.

BACHELARD, Gaston. A poética do espaço. Trad. Antônio de Pádua Danesi. São Paulo: Martins Fontes, 1988.

BACHELARD, Gaston. A terra e os devaneios do repouso: ensaio sobre as imagens da intimidade. Trad. Paulo Neves da Silva São Paulo: Martins Fontes, 1990.

BORGES, Jorge Luis. GUERRERO, Margarita. O livro dos seres imaginários. Trad. Carmen Vera Cirne Lima. São Paulo: Globo, 2000.

CAMPELLO, Eliane. A tessitura da escrita: do mito à expressão pela arte. Interdisciplinar: revista de estudos em língua e literatura. v. 7, n. III, 2008.

DURAND, Gilbert. As estruturas antropológicas do imaginário: introdução à arquetipologia geral. Trad. Hélder Godinho. São Paulo: Martins Fontes, 2012.

GAIMAN, Neil. Mitologia nórdica. Trad. Edmundo Barreiros. Rio de Janeiro: Intrínseca, 2017.

GRIMM, Jacob; GRIMM Wilhelm. A bela adormecida. In: Contos de fadas de Perrault, Grimm, Andersen e outros. Trad. Maria Luiza X. de. A. Borges. Rio de janeiro: Zahar, 2010.

GRIMM, Jacob; GRIMM Wilhelm. Rumpelstiltskin. In: Contos dos irmãos Grimm. Organizado, selecionada e prefaciado pela Dra. Clarrisa Pinkola Estés. Trad. Lia Wyler. Rio de Janeiro: Rocco, 2005.

HOMERO. Odisseia. Trad. Christian Werner. São Paulo: Cosac Naify, 2014.

IMBROISI, Margaret; MARTINS, Simone. As Fiandeiras, Velázquez. História das Artes, 2020. Disponível em: <https://www.historiadasartes.com/sala-dos-professores/asfiandeiras-velazquez/>. Acesso em 13 Nov 2020.

LIBOREL, Hughes. As fiandeiras. In: Dicionário de mitos literários. Trad. Carlos Sussekind et al. Rio de Janeiro: José Olympio, 2005.

MACDONALD, George. A princesa e o goblin. Trad. Keila Litvak. São Paulo: Landy, 2003. 
G. Soncini A figura da velha fiandeira na tessitura de caminhos na obra A princesa e o Goblin de George Macdonald

MACHADO, Ana. Maria. O Tao da teia: sobre textos e têxteis. Estudos Avançados, 17 (49), 173-196, 2003.

OVÍDIO. Metamorfoses. Trad. Vera Lucia Leitão Magyar. São Paulo: Madras, 2003.

NOVALIS, F. Von. H. Pólen. Trad. Rubens Rodrigues Torres Filho. São Paulo: Iluminuras, 2001.

Wilde, Lady. As mulheres chifrudas. In: Os melhores contos de fadas celtas. Trad.

Cláudia Mello Belhassof et al. São Caetano do sul: Editora Wish, 2020.

Artigo recebido em: 28.08.2020

Artigo aceito para publicar em: 04.11.2020 